\title{
The Representation of the Operation Anthropoid in Selected Works
}

\author{
Büke Sağlam (Santiago de Compostela)
}

\begin{abstract}
The Operation Anthropoid, carried out by Jan Kubiš and Jozef Gabčik, has become a recurrent theme in literature and popular culture. Using Laurent Binet's HHhH, its movie adaptation The Man with the Iron Heart, the movie Anthropoid, Leopold Lahola's play Assassination (Atentát) as well as Howard Linskey's Hunting the Hangman, this article focuses on the representation of the Operation in historical fiction while analyzing various concepts such as fear, cruelty, brotherhood, conscience and guilt to better understand what do both Heydrich and the assassins symbolize. Therefore, the symbolic aspect of an assassination, emphasizing both the roles and the national identities of the assassins and of Heydrich himself as well as its fictionalization using different tools will be investigated along with the narration and the conceptualization of a socio-political event. Finally, this paper will try to understand the process of recreating a past incident and see its connection with the present.
\end{abstract}

\section{Key words}

historical fiction; Operation Anthropoid; Czechoslovak identity; Laurent Binet; Leopold Lahola; Howard Linskey

\section{Abstrakt \\ Prezentace operace Antropoid ve vybraných dílech}

Operace Antropoid, provedená Janem Kubišem a Jozefem Gabčíkem, se stala znovu se vracejícím motivem v literatuře a populární kultuře. Studie, která analyzuje knihu Laurenta Bineta $H H h H$, jeho filmovou adaptaci Smrtihlav (The Man with the Iron Heart), film Anthropoid, hru Atentát od Leopolda Laholy, stejně tak knihu Howarda Linskeyho Hunting the Hangman (Honba za katem), se zaměruje na prezentaci této události v historické próze. V souvislosti s tím zároveň hodnotí rưzná pojetí lidského chování jako strach, krutost, bratrství, svědomí, vina, aby bylo lépe porozuměno tomu, co Heydrich a atentátníci symbolizují. Studie proto zkoumá i symbolický aspekt atentátu akcentujicí jak úlohu národní identity atentátníků a samotného Heydricha, tak i beletrizaci, v niž se uživá různých nástrojů spolu s vyprávěním a konceptualizací této společensko-politické události. Nakonec si toto pojednání klade za cíl prostřednictvím umělecké rekonstrukce porozumět této události z pohledu současnosti.

\section{Klíčová slova}

historická beletrie; operace Antropoid; československá identita; Laurent Binte; Leopold Lahola; Howard Linskey 


\section{Introduction}

One of the most important, shocking, and famous historical assassinations that changed the course of history is, beyond any doubt, the assassination of the Reich Protector of Bohemia and Moravia, Reinhard Heydrich. The uniqueness of this assassination mainly derives from two factors: the importance of the target and the selfless attitudes of the assassins. The assassination - or maybe it would be more convenient to define it as a suicide mission - was carried out by Jozef Gabčík and Jan Kubiš, two soldiers from the Czechoslovak army-in-exile, trained by the British Special Operations Executive. On 27 May 1942, Gabčík stepped in front of Heydrich's car and fired with his Sten but it jammed. Afterwards, Kubiš threw an anti-tank grenade which damaged the car and managed to wound Heydrich. He died several days afterwards, on 4 June 1942. The assassination of one of the most high-ranking and brutal Nazi officials not only affected history, but also became a recurrent theme in literature and movies. Laurent Binet's historical novel HHhH, which stands for Himmlers Hirn heisst Heydrich (which can be translated as "Himmler's brain is called Heydrich"), its movie adaptation with the title The Man with the Iron Heart, the movie Anthropoid as well as the play Assassination by Leopold Lahola, Callum MacDonald's The Assassination of Reinhard Heydrich and Howard Linskey's Hunting the Hangman are some of the works which specifically investigate the Operation Anthropoid. Though the main event remains constant, each work has a different point of view and enables the audience to understand the details, nature, and the impact of the assassination in a more profound and versatile way. Not only the assassins but also the target, "The butcher of Prague", raises attention because of his exceptional cruelty and inhuman personality traits. A historical event starring idealist and courageous assassins, Heydrich and a risky assassination plan sounds more like a story with archetypes than a real event. So, it is no surprise that the event and its protagonists have become a great inspiration for many writers and playwrights. Of course, the most convenient literary genre to explain and narrate such an incident would be historical fiction.

We see some of the most successful examples of historical novels and history plays that deal with the Operation Anthropoid in Binet's and Linskey's novels and Lahola's play. However, before analyzing them in a more profound way, it would be better to talk about the genre's characteristics first. Jerome De Groot states:

"A historical novel might consider the articulation of nationhood via the past, highlight the subjectivism of narratives of History, underline the importance of the realist mode of writing to notions of authenticity, question writing itself, and attack historiographical convention. The form manages to hold within itself conservatism, dissidence, complication and simplicity; it attracts multiple, complex, dynamic audiences; it is a particular and complex genre hiding in plain sight on the shelves of a bookshop [...]

1 As Binet states it in HHhH. (BINET, Laurent: HHhH. Trans. by Sam Taylor. New York: Picador, 2012, p. 129). 
historical fiction is written by a variety of authors, within an evolving set of sub-genres, for a multiplicity of audiences." 2

The versatile approach of historical fiction indeed offers a great way to understand not only the historical event but also the psychological conditions, beliefs, thought processes, and lives of the lead actors of the incident. It enables the reader to truly empathize with the protagonists, imagining the time period in question and making deductions based on today's point of view. Thus, a historical novel requires the active participation of the reader and separates itself from other genres where the readers would remain as mere spectators ${ }^{3}$. Since a historical novel is based on real historical events and facts, it also gives us the opportunity to physically see the places that are important for the event and immerse ourselves in them. Actually, we already know that both Binet and Linskey travelled to Prague and tried to visit all of the places that are linked to Operation Anthropoid while gathering information about the details of the event. As Linskey said during an interview: "I flew to Prague to see all the major locations in the story and even managed to find some places that only feature briefly, such as the exiled Czech president Eduard Beneš' house in Aston Abbotts, Buckinghamshire. To be honest I immersed myself in this story." Moreover, historical fiction allows the writer to combine different genres, such as thriller or crime, to enrich the narration. It is no coincidence that Linskey is best known as a crime author, and Hunting the Hangman clearly includes the elements of a thriller. Another important aspect of historical fiction would be the element of the uncanny. As De Groot indicates:

\begin{abstract}
"History is other, and the present familiar. The historian's job is often to explain the transition between these states. The historical novelist similarly explores the dissonance and displacement between then and now, making the past recognizable but simultaneously authentically unfamiliar [...] The figures we meet in historical fiction are identifiable to us on the one hand due to the conceit of the novel form, in that they speak the same language, and their concerns are often similar to ours, but their situation and their surroundings are immensely different." ${ }^{5}$
\end{abstract}

As Freud states: "the uncanny is that species of the frightening that goes back to what was once well known and had long been familiar." 6 The uncanny element in historical fiction is our understanding of the past. Looking back at history, the historical novelist tries to

2 DE GROOT, Jerome: The Historical Novel. London and New York: Routledge, 2009, p. 2.

3 " [...] The historical novel as a form is something which demands an unusual response from its audience: an active response, at the least, and a sense of otherness and difference when reading. The historical novel, then, is similar to other forms of novel-writing in that it shares a concern with realism, development of character, authenticity. Yet fundamentally it entails an engagement on the part of the reader (possibly unconsciously) with a set of tropes, settings and ideas that are particular, alien and strange" (Ibidem, p. 4).

4 LINSKEY, Howard: Hunting the Hangman, QE'A with author Howard Linskey. Interview by Abby Slater-Fairbrother. Anne Bonny Book Reviews, May 18, 2017. https://annebonnybookreviews.com/tag/operationanthropoid.

5 DE GROOT, Jerome: The Historical Novel. London and New York: Routledge, 2009, p. 3.

6 FREUD, Sigmund: The Uncanny. Trans. by David McLintock. London: Penguin Books, 2003, p. 124. 
comprehend a specific incident in the past by trying to imagine the unimaginable and presents it to today's reader. Some past event, which was once very familiar for some people, would be totally unknown or unfamiliar for the next generation or after various decades. Heydrich's cruelty directly affected the Czech population during the WW2, but today his name certainly doesn't stress the millennials out as much as it did the people during wartime. The historical novelist deals with - once a familiar - unfamiliar incident and tries to narrate it as comprehensible as possible for today's reader, making it familiar again. This process would create an uncanny effect on the reader. As Linskey commented on writing about Heydrich in his novel Hunting the Hangman: "It was difficult to write those chapters because I had to try and get inside his head, to view the world like he did, and his world view was extremely disturbing. I also wanted to show how these people could appear normal, even loving, in the right context, with their families for example [...] Each chapter heading has a real quote from a senior Nazi; a device I used to show I was in no way exaggerating their twisted views." ${ }^{7}$ Imagining the past and trying to immerse in a past event in order to narrate it for today's audience is already a pretty uncanny experience, not to mention being inside one of the most disturbing minds of all time. While empathizing both with the "heroes" and the "villains" of the selected historical event, the historical novelist tries to recreate the dialogues, thoughts, and sentiments of the people as accurately as possible. In the following chapter, the elements that would constitute a successful historical fiction will be investigated, analyzing the mentioned works.

\section{The Heroes and the Villain}

What makes a historical novel different and interesting is clearly its protagonists as much as the historical event itself. It is highly normal that many writers were intrigued by the Operation Anthropoid, and the event was narrated constantly both in literature and on the silver screen. The antagonist of the Operation is, clearly, Reinhard Heydrich. His profile, as a SS official, is a typical one with his ambitious and merciless character and his Aryan appearance. What makes him more different than other high-ranking Nazi officials, like Himmler, is the sensation he arouses. Somehow, he achieved to become a concept rather than a flesh and blood man through his techniques and character, which made him even more fearful. The names ${ }^{8}$ he was given, such as "the butcher of Prague", "the blond beast", "the man with the iron heart", "the hangman", etc., all support the concept he stands for. One can't help but remember the various nicknames given to almost all kinds of killers (mostly serial killers) to create a higher impact on the society. As Jack Levin and James Alan Fox state:

7 LINSKEY, Howard: Hunting the Hangman, QE'A with author Howard Linskey. Interview by Abby Slater-Fairbrother. Anne Bonny Book Reviews, May 18, 2017. https://annebonnybookreviews.com/tag/operationanthropoid.

8 The nicknames given to Heydrich can be found in the works I mentioned, but also, they can be seen altogether in: https://www.imdb.com/name/nm0382193/bio. 
"When Newsweek magazine dubbed the Washington-area sniper the 'Tarot card killer' and boldly featured the moniker on its cover last week, we couldn't help but shudder. Giving the sniper such a memorable, even glamorized, nickname would ensure that he takes his place among those many other serial killers who have become household names: Son of Sam, Green River killer, Hillside Strangler, Unabomber [...] Certainly the instinct to label the killer in some colorful way is natural enough. But as criminologists who have studied serial killers for more than 20 years, we know that naming a dangerous criminal like this can do more than sear him in the public's collective memory. It may also encourage him to fulfill our expectations." 9

Clearly, Heydrich was not a serial killer, however, his own personality, along with the Nazi propaganda, created almost the same impact on the people and transformed him into a monstrous concept. This psychological trick of giving catchy names, emphasizing both his cruelty and even his high sexual energy ${ }^{10}$, still continues when we see his portrayal in various literary works and documentaries. It was crucial turning him into a concept for two basic reasons: Through Heydrich, Nazis tried to make people believe in the indestructibility of the Nazi regime, and, today, they still use this trick for marketing and commercial reasons. Again, it is somewhat similar to the position of the serial killers in a consumer culture. As Brian Jarvis comments:

\begin{abstract}
"Serial killing [...] has become big business within the culture industry [...] Hobbs investigates the burgeoning market for 'murderabilia' and follows enthusiasts in this field who avidly build collections which mirror the serial killer's own modus operandi of collecting fetish objects. Murderabilia ranges from a serial killer art [...] to body parts [...] from crime scene materials to kitsch merchandizing that includes serial killer T-shirts, calendars, trading cards, board games, Halloween masks and even action figures of 'superstars' like Ted Bundy, Jeffrey Dahmer and John Wayne Gacy."11
\end{abstract}

It wouldn't be wrong to claim that Reinhard Heydrich has become one of the "superstars" among the Nazis, and his fame as a cruel killer continues to get bigger even today in popular culture. Stating how Himmler, as well as other Nazi officials, were abstained and somehow frightened by him only helps to make him even more "interesting" in the eyes of the public. Laurent Binet writes in his historical novel:

\footnotetext{
"You are strong, you are powerful, you are pleased with yourself. You have killed people and you are going to kill many, many more. Everything you do succeeds. Nothing can resist you. In the space of barely ten years you have become »the most dangerous man in the Third Reich." [...] They call you the Blond Beast [...] Everyone is afraid of you, even your boss-a bespectacled little hamster, albeit a dangerous one." 12
}

9 LEVIN, Jack - FOX, James Alan: Making Celebrities of Serial Killers Elevates Threat, 2002. https://web. northeastern.edu/jfox/Columns/usatoday\%20monikers\%20oct\%2023.htm. Accessed May 2020.

10 "Heydrich, the Blond Beast, who, through his ferocity but also through his sexual performances, is doubly deserving of his nick-name." (BINET, Laurent: HHhH. Trans. by Sam Taylor. New York: Picador, 2012, p. 117).

11 JARVIS, Brian: Monsters Inc.: Serial Killers and Consumer Culture. Crime Media Culture 3, 2007,3 , p. 327.

12 BINET, Laurent: HHhH. Trans. by Sam Taylor. New York: Picador, 2012, p. 253. 
Heydrich was indeed powerful, and his power derived mainly from his capacity of arousing fear. However, this power was actually created and supported by the Nazi regime with an aim to impress and frighten people. The interesting point is how they are "selling" him even today using the same nicknames that were used before, during the Nazi regime. The fetish with what is "sadist", "creepy" or "frightening" is still valid in today's consumer culture and is not only limited to serial killers but also includes Nazi officials.

Clearly, Heydrich portrays a perfect modern villain and his name is used even for a vampire, who is the main villain in two issues of the series of role-playing gamebooks called Fighting Fantasy. In the series, we see him as Count Reiner Heydrich (or as Count of Mortvania). Mortvania, in this case, clearly represents Prague. Resurrecting Heydrich with his own name in the form of a vampire may seem uncanny at first, but actually it would be possible to imagine him as a modern Gothic villain (or a vampire) because of the "power" he represents. Talking about George R.R. Martin's Feure Dream McLennon suggests:

"In Martin's text, evil vampires are used as a metaphor for the white human slaver. Evil vampires treat humans as animals, just as white humans treat black slaves as animals. [...] For their own pleasure, evil vampires drain the lives of black slaves. In this unsettling socio-ecological hierarchy, the vampire is a superior master who consumes inferior human animals. These humans are merely lower on the food chain than vampires [...] This hierarchy of vampiric predation destabilizes the boundaries between vampire and human, suggesting that humans are vampires to other humans." 13

Throughout history, Heydrich was anything - a monster, a vampire, a beast - but a human being and for this very reason, his assassination was something almost compulsory. There couldn't be a better target to kill in order to end the illusion of the existence of some alien or animal-like creature with somehow superior powers. Also, there couldn't be a better name for this Operation than Anthropoid, meaning "having the form of a human" or "resembling a human being" in Greek ${ }^{14}$. As we can see in the documents written by the Ministry of Defence of the Czech Republic:

"In such a situation it was necessary to prepare an enterprise that would clearly show the home resistance movement's anti-German stance while simultaneously demonstrating President Benes's control of the situation in the home country. The terror unleashed by Heydrich in the Protectorate was another reason for planning his assassination. The assassination was considered an act of just retribution. At the same

13 MCLENNON, Leigh M.: 'The Red Thirst is on this Nation': Vampiric Hauntings and the American Civil War. In War Gothic in Literature and Culture, ed. by Agnieszka Soltysik Monnet - Steffen Hantke. New York: Routledge, 2016, p. 11-12.

14 "The operation was given the codename Anthropoid, Greek for 'having the form of a human', a term usually used in zoology." (Wikipedia.com/ Operation Anthropoid) or "Anthropoid is formed from the Greek word for human being, anthrōpos and the ending -oid, meaning 'resembling'. Anthropoid can describe fictional animals that look like humans." (vocabulary.com/dictionary/anthropoid). 
time it was meant to prove to the Nazis that none of them was untouchable and might anytime be called upon to account for their actions." 15

While the representation of Heydrich slightly changes from one movie to another, the portrayal of the assassins remains more or less the same. In The Man with the Iron Heart, we witness the aggressive and impulsive side of Heydrich. Portrayed by Jason Clarke, we see him having a temper tantrum after he was expelled from the German Navy. In another scene, he is willing to personally beat or kill the opponents. Rather than a cold-blooded and self-controlled Nazi official we see him as a time bomb ready to explode. In Conspir$a c y$, Heydrich is portrayed by Kenneth Branagh and the audience sees a totally different Heydrich with his calm, decisive, controlling, and sharp attitudes during the Wannsee Conference where the Nazi officials discuss the "Final Solution". In the movie, he has total control over every other Nazi official without any significant effort. His ability to manipulate and persuade shows his keen intelligence as well as his cynical and calculating nature. This fact demonstrates that he is more than a random impulsive man who is only capable of doing dirty works. ${ }^{16}$ Though, his cruelty and ruthlessness can still be seen through his every line and especially in his basic idea, which is the extermination of the Jews. In one scene, he sarcastically comments on the idea of Dr. Wilhelm Kritzinger: "Well then, this is the moment to be...practical, until such time as Germany can afford your philosophy, which is what? Hound them, impoverish them, exploit them, imprison them, just do not kill them, and you are God's noblest of men. I find that, uh, truly remarkable." 17

What makes Heydrich a real monster may be his overly direct attitude in saying or doing things. Clearly, he had no moral preoccupations or any kind of conscience just like other Nazi officials. But the difference between him and other officials was that Heydrich was a man of action. He didn't hesitate to do or say anything immoral while others tried to be more "politically correct". In the lines above, Kenneth Branagh's Heydrich clearly shows how all the Nazis are actually the same and that no one is better than the other one in any way. Moreover, he was very good at finding and showing the weaknesses of the others, which made him even more powerful. As Callum MacDonald states: "Schellenberg described his chief [Heydrich] as a born intriguer with 'an incredibly acute perception of the moral, human, professional and political weaknesses of others... His unusual intellect was matched by the ever watchful instincts of a predatory animal." ${ }^{18}$ In that sense, Branagh created a pretty convenient portrayal of Heydrich in Conspiracy, reflecting his cold-blooded but also vicious attitude.

Heydrich seemed to understand and accept his very nature, and, as he acted accordingly, he eventually had become a "beast", a "predatory animal" or an "anthropoid". In

15 BURIAN, Michal - KNÍŽEK, Aleš - RAJLICH, Jiří - STEHLÍK, Eduard: Assassination. Trans. by Janua Agency. Prague: Ministry of Defence of the Czech Republic, 2002, p. 31.

16 As Callum MacDonald comments: "For him it was no longer enough to be head of the security police. He wanted to be more than 'the dustbin of the Reich', the man who did the dirty works for others." (MACDONALD, Callum: The Assassination of Reinhard Heydrich. Edinburgh: Birlinn Limited, 2007, p. 127).

17 PIERSON, Frank - LORING, Mandel: Conspiracy. Video Film Express, DVD, 2001.

18 MACDONALD, Callum: The Assassination of Reinhard Heydrich. Edinburgh: Birlinn Limited, 2007, p. 5. 
different works, we constantly see the same description of him; cold, fearful and animallike. As MacDonald comments:

"His own protégé, Walter Schellenberg, who later rose to head the German intelligence service, found his very appearance sinister: »He was tall, impressive figure with a broad, unusually high forehead, small restless eyes as crafty as an animal's and of uncanny power, and a wide full-lipped mouth.«"19

It is no surprise that in popular culture we see him as a vampire (again, a mixture of human and animal) as both his appearance and personality as well as his gestures and attitudes clearly resemble a dangerous animal rather than a human being. While one may ask whether we still continue to be "tricked" by the old Nazi propagandas and by today's consumer culture and somehow glamorize Heydrich with exaggerations, consciously or unconsciously, one thing is for sure that he was-and still is-a perfect villain archetype and it is always more "appealing" to talk about a villain than a hero. Indeed, the reason why the case of Heydrich is more "interesting" than a simple villain would be because of the fact that he seems to be the compound of different villain archetypes such as "the beast", "the mastermind" and "the henchman"20. The beast is described as a "classic villain whose goal is to terrorize and attempt to defeat the main character, the beast is a literal monster"; the mastermind, on the other hand, "opposes the protagonist by overseeing a brilliant, diabolical master plan. They are gifted schemer and evil genius who attempts to defeat the protagonist mentally as opposed to physically." The henchman, which is the total opposite of the mastermind, "exists to do the dirty work of someone else, usually the mastermind or another major evil character in the story." ${ }^{21}$ Heydrich, described as a beast, was capable of being both the mastermind and the henchman as we can see in Conspiracy and in The Man with the Iron Heart. As Binet states: "[...] it must be admitted that in literary terms Heydrich is a wonderful character. It is as if a Dr. Frankenstein novelist had mixed up the greatest monsters of literature to create a new and terrifying creature. Except that Heydrich is not a paper monster." ${ }^{22}$ However, in Operation Anthropoid, the heroes are as interesting and versatile as the villain. Both in the movie Anthropoid and in the play Assassination, we are not given any details about Heydrich. In Anthropoid, the focus is on the assassins, Gabčík and Kubiš portrayed by Cillian Murphy and Jamie Dornan. We see how they prepare for the assassination, how they commit it, and the aftermath. In Lahola's play, the story takes place after the assassination when the assassins are hiding in the crypt. Both in The Man with the Iron Heart and in Anthropoid the portrayal of the assassins is more or less the same. In both movies, we see their brotherhood, mutual trust, naivety, and the desire for self-sacrifice for the sake of their country. Though during that era Czechoslovakia was already separated and Czech lands were occupied by German forces, while Slovakia was an independent satellite state, both assassins fought for the freedom of Czechoslovakia by targeting Re-

19 Ibidem.

208 Villain Archetypes: How to Write Different Types of Villains. MasterClass, 2020. https://www.masterclass. com/articles/how-to-write-different-types-of-villains\#8-villain-archetypes. Accessed May 17, 2020.

21 Ibidem.

22 BINET, Laurent: HHhH. Trans. by Sam Taylor. New York: Picador, 2012, p. 99. 
ichsprotektor of Bohemia and Moravia. The assassination plan conducted by two young soldiers is heroic, and the selection of the two soldiers' nationalities seems to be symbolic. As Binet comments:

"The Resistance is dying, so reinforcements must be sent from abroad [...] who will accomplish a mission that sends out shock waves, nationally and internationally. It must impress the Allies by showing them that Czechoslovakia cannot be counted out, and at the same time it must stimulate Czech patriotism so that the Resistance can rise once again from the ashes. I say 'Czech patriotism,' but I am also pretty sure that Beneš was the one who insisted that Moravec choose a Czech and a Slovak to carry out the operation. Two men to symbolize the indivisible unity of the two peoples." ${ }^{33}$

A very similar comment was made by Howard Linskey in Hunting the Hangman while describing the process of selection of the two men for the Operation:

"There was one stipulation, however; a little less noble but designed to ignite the dampened flame of nationalist fervor in occupied Czechoslovakia; one of the men had to be a Czech and the other a Slovak. Thus, the two former halves of the republic would strike back in unison at the evil forces of occupation." ${ }^{24}$

In the end, the assassination was committed by Josef Gabčík and Jan Kubiš, however before Kubiš, the second assassin was going to be Karel Svoboda. As MacDonald states:

"It seemed to Moravec that these two men possessed the qualities he needed. They were proficient soldiers, brave, patriotic and could be relied upon to obey their orders without question. These factors were reinforced by another consideration. Gabčik was a Slovak and Svoboda was a Czech, a combination which had not occurred by accident. The two men were to symbolize the nation founded by Tomaš Masaryk and Eduard Beně̌." 25

All of the three authors, Binet, MacDonald and Linksey, share the same idea about the symbolism created by the selection of Czech and Slovak soldiers for the Operation. Svoboda was replaced by Kubiš, and obviously, he was never present during the process after he got injured. However, in Lahola's play Assassination, we see him as a character in the crypt with his cover name, Jacob, along with Kubiš (cover name, Mark). Written in 1949 by a Slovak playwright, writer and director Leopold Lahola, the play is highly interesting for various reasons. While it deals with the Operation Anthropoid as $H H h H$ and Hunting the Hangman do, Assassination shows us a totally different point of view, using Christian elements. In the play, both the assassins in the crypt and the German lieutenant are encouraged to contemplate on their intentions and actions particularly by a man named Jesus. The philosophical and religious tone of the play makes the reader think about various abstract concepts such as justice, evil, defense, crime, sin and goodness,

23 Ibidem, p. 149-150.

24 LINSKEY, Howard. Hunting the Hangman. Harpenden: No Exit Press, 2017, p. 69.

25 MACDONALD, Callum: The Assassination of Reinhard Heydrich. Edinburgh: Birlinn Limited, 2007, p. 144. 
thus, enriches the narrative. The play's difference from the other works which discuss the Operation derives from its detailed character analysis and philosophical tone. Indeed, the play can be considered as a psychoanalytical work since, through the character of Jesus, the reader is encouraged to comprehend the thought processes and the mental states of the people in both sides. Even at the beginning of the play, we are given "Notes about the nature of characters" ${ }^{26}$. The character of Lucas, who resembles Gabčík but represents a fictional commander, is described as the "oldest paratrooper" and "one cannot immediately tell that under his strong, confident, cynical surface he hides an amazing goodness, which he disguises and which he finds embarrassing" ${ }^{\prime 27}$. While Mark (Kubiš) is described as the younger one who is "self-absorbed, almost self-torturing, moody man who will do things that nobody would expect from him" 28 .

The personality descriptions of the two assassins coincide with the descriptions of Binet: "Gabčk ful and easygoing. ${ }^{29}$ In his novel, Binet also cites Colonel Moravec's thoughts about these two men. Moravec describes Gabčík as follows: "He showed himself to be talented, clever and cheerful, even in the most difficult situations. He was open, warm-hearted, enterprising and resourceful. A natural born leader." ${ }^{30}$ As for Kubiš, Moravec states that "He was very disciplined, discreet and reliable. He was also very calm, reserved and serious -the complete opposite of Gabč̌k's merry, outgoing personality." ${ }^{11}$

We have already seen all these personality traits of both Gabčík and Kubiš in the mentioned movies. We see them in Lahola's play too, but with some considerable modifications. For instance, the character of Lucas seems to have similar personality traits of Gabčík however he has the role of a commander and has not actually been with Kubiš during the time of the assassination. Also, according to the play, the assassination was carried out only by Mark throwing a grenade to the target after Jacob got injured. There is no mention of Gabčík's jammed Sten, and Kubiš (Mark) seems to be alone while committing the assassination even though the play mentions someone called Paul to whom Mark was supposed to report and stay close. Apart from these alterations, the two main protagonists of the play seem to have the same characteristics as Kubiš and Gabčík. Even from the dialogue between Mark and Lucas at the beginning of the play, and from the descriptions, the reader can understand how opposite they are regarding their personalities just as they were in real life. The play begins in the crypt with the action description of the two characters. While Mark is "sitting, absent-mindedly drawing images in the air with the finger of his slouched arm"32, Lucas is "on the highest step leading to

26 LAHOLA, Leopold: Assassination. Eds. Vladimír Štefko - Slugeňová Cockrell, Katarína. Golden Collection of the Slovak Drama of the 20th Century (1900-1948). Bratislava: Divadelný ústav, 2016, p. 13.

27 Ibidem.

28 Ibidem.

29 BINET, Laurent: $H H h H$. Trans. by Sam Taylor. New York: Picador, 2012, p. 156.

30 Ibidem.

31 Ibidem.

32 LAHOLA, Leopold: Assassination. Eds. Vladimír Štefko - Slugeňová Cockrell, Katarína. Golden Collection of the Slovak Drama of the 20th Century (1900-1948). Bratislava: Divadelný ústav, 2016, p. 4. 
the cover, watching through the crack of the slightly open cover what is happening in the church. He runs downstairs." ${ }^{33}$ The differences between the two characters are also represented quite clearly in the movie, Anthropoid. Cillian Murphy's Gabčík is also the dominant one between the two, with his more decisive and cold-blooded attitudes. Jamie Dornan's Kubiš, on the other hand, seems to be more passive, emotional and quiet. He hopes to stay alive after the operation, while Gabčík has already acknowledged the fact that it will be a suicide mission, and both of them will die after they commit the assassination, if not during the attempt. In the movie, we see Kubiš deciding to marry his girlfriend, Marie (portrayed by Charlotte Le Bon), while Kubiš and Gabčík are in the process of preparation for the assassination, which indicates his hope and will to live. After their announcement of marriage, Gabčík asks Kubiš: "Why are we here?" When Kubiš answers by revealing his hope for the cancelation of the operation, Gabčík continues by saying: "You're lying to yourself, my friend. Because it is easier" after which Kubiš responds: "I have to believe there is a way through this. That there is a normal life waiting for us. The way things used to be. Marie makes me feel that there is hope." Again, this fictional conversation points to Kubišs's naive and emotional nature while representing Gabčík as a more mature and realistic individual.

It is no surprise that at the beginning of Lahola's play, Mark almost seems to lose his mind, that he cannot believe or is not sure whether he threw the grenade to Heydrich or not. First, we see him in a total catatonic state, then asking repeatedly to Lucas, who was the person that threw the grenade before he re-establishes his contact with reality. Thanks to Lahola, we clearly see Mark's mental struggle, the way he can't deal with the ongoing traumatic situation, and his psychological dissociation. When he remembers the moment of the assassination, he says: "You know, Lucas, that - what's his name, he was looking at me from the first moment [...] The fellow in the car. He knew for sure that I was going to kill him." 34 to which Lucas replies: "So what? They say every animal can sense its death. So this animal sensed it too." ${ }^{35}$ In the play, the name "Heydrich" is never mentioned, the characters either use the term Reich Protector or, as we repeatedly see both in real life and fiction, they prefer to call him an animal. However, rather than glamorizing Heydrich or out of fear, Lahola calls him an animal as a pure humiliation, showing him as an inferior creature who does not even deserve to be called by his own name.

As we mentioned before, Assassination makes the reader think about the possible psychological outcomes of the assassination and the mental states of the paratroopers while they are hiding in the crypt after the Operation. The first and most obvious psychological symptoms are shown by Mark. These symptoms can easily be interpreted as the symptoms of posttraumatic stress disorder (PTSD). Taking into consideration the extreme situation Mark has been experiencing, his symptoms are not surprising at all. At the beginning of the play, Lucas tries to talk to him, asking simple questions like if he is hungry but cannot receive any proper answer. The play's description of Mark, that

33 Ibidem.

34 Ibidem, p. 8.

35 Ibidem. 
he is "sitting apathetically, almost guiltily, his behavior shows that he experienced something that takes away his fancy to talk"36 sounds like the medical definition of the symptoms of PTSD. According to Posttraumatic Stress Disorder: Clinical Features, Pathophysiology, and Treatment:

"Patients with PTSD may attempt to avoid thoughts or activities related to the trauma. There may be a markedly diminished capacity to experience pleasure (anhedonia), difficulty in remembering aspects of the trauma, blunted affect, a feeling of detachment or estrangement from others, and a perception of a foreshortened future." 37

When Lucas reminds him of the instructions of the operation that Mark was supposed to follow, he cannot give attention and doesn't even seem to remember them. We see him totally dissociated and numb. He avoids to talk and is unable to concentrate during their conversation with Lucas. Avoidance and apathy are obvious as several of his first reactions after the Operation. Another reaction worth considering is his attitude when he hears the word "grenade". When Lucas sarcastically "reminds" Mark about the orders, he mentions the part where Mark throws the grenade to Heydrich. After hearing the word "grenade", Mark starts to asks repeatedly: "You know, Lucas, whatever happened to that grenade? Did someone throw it? [...] Who threw the grenade? Well? I am asking who threw the grenade?" 38 With this last line, we are also given a description: "shock is growing in him like an avalanche." ${ }^{9}$ The following description represents the climax of his mental struggle while repeating the same question: "Stands up, threateningly" 40 These repetitive questions and thoughts about the source of his trauma (which is committing an assassination, throwing a grenade) and his radical mood swings (first being totally numb and indifferent, after being nervous and highly stressed out and finally being aggressive and threatening) perfectly represent two groups of symptoms of PTSD which are "persistent avoidance of stimuli associated with the trauma and numbing of general responsiveness" and "persistent symptoms of increased arousal" which include "irritability or outbursts of anger", "difficulty concentrating" and "exaggerated startle response" (2006, 385). Moreover, by asking compulsive questions about the grenade, Mark seems to be unable to fully remember the most important part of the assassination he committed. This kind of reaction is also considered one of the very typical symptoms of PTSD, mentioned in the article as the "inability to recall an important aspect of the trauma" ${ }^{41}$. Finally, Mark's first mental shock seems to come to an end, repeating the same question, but this time, accompanied by

36 Ibidem, p. 5.

37 VIEWEG, W. - VICTOR, R. - DEMETRIOS, A. Julius [et al.]: Posttraumatic Stress Disorder: Clinical Features, Pathophysiology, and Treatment. The American Journal of Medicine 119, 5, 2006, p. 385.

38 LAHOLA, Leopold: Assassination. Eds. Vladimír Štefko - Slugeňová Cockrell, Katarína. Golden Collection of the Slovak Drama of the 20th Century (1900-1948). Bratislava: Divadelný ústav, 2016, p. 7.

39 Ibidem.

40 Ibidem.

41 VIEWEG, W. - VICTOR, R. - DEMETRIOS, A. Julius [et al.]: Posttraumatic Stress Disorder: Clinical Features, Pathophysiology, and Treatment. The American Journal of Medicine 119, 5, 2006, p. 385. 
another mental state. Neither aggressive nor nervous, Mark is described as "obsessed with the image, he is getting desperate" 42 .

After all these mood swings, as it is expected from a person with PTSD, Mark seems to finally find his peace of mind, as Lucas commented. ${ }^{43}$ Mark's psychological struggle indicates the fact that all he wants is to "verify" the ongoing shocking situation, by hearing it from a third person, in order to be able to believe that the event actually happened, as all the process sounds too surreal to him ${ }^{44}$. Mark asks it to Lucas in a rather obvious way: "I would still like to hear from your mouth who took the safety off the grenade under the coat one inch from his own guts, who counted to three at the intersection, and who slammed it into the limousine exactly according to the orders?" 45 The detailed description of the assassination both makes the reader visualize the Operation and reveals the fact that Mark hasn't actually forgotten the event but needed to complete the circle step by step (numbing, avoidance, increased arousal) before being able to confront the incident and make peace with himself.

Although they were assassins, both Kubiš and Gabčík were not cold-blooded murderers or psychopaths. On the contrary, they were too humane and naïve, a thing that can be interpreted as a tragedy, considering their positions. Both in the movies and in the play, we see their continuous suffering and anxiety, even if they know that the assassination of Heydrich is something necessary for their country and is totally just. Doubts, a sense of guilt, self-torture and self-judgment have always been present before and after the assassination. For this reason, the character of Jesus in Lahola's play, who obviously represents Jesus Christ, is very in point.

In the beginning of Act II, the description mentions a statue of Christ in the church that comes to life at the end of the act. The role of Jesus becomes clear when he, pointing at Mark, says: "This one. He would have been responsible for taking a human life...How should I put it...He would feel like a murderer, and he would have been one." To which, Mark reacts, "jumping up: "Who's a murderer? Who's a murderer here? Who?"46 Clearly, through Jesus, we understand what Mark thinks and the way he feels. Jesus makes Mark confront with the feelings and the fears he would like to avoid. His role as Mark's subconscious or inner voice gives us an idea about how the assassins would have felt and what would have been their mental condition after the Operation. In that sense, Lahola's play becomes unique by focusing not only on the Operation itself but also on its psychological impact on the assassins, which is not fully represented in the movies. However, in Assassination, Jesus represents the inner voice not only of Mark but also of $\mathrm{Jacob}^{47}$ and the

42 LAHOLA, Leopold: Assassination. Eds. Vladimír Štefko - Slugeňová Cockrell, Katarína. Golden Collection of the Slovak Drama of the 20th Century (1900-1948). Bratislava: Divadelný ústav, 2016, p. 7.

43 In the play Lucas says: "Finally you found your peace of mind." (Ibidem, p. 8.).

44 "I kept thinking that it would blow up early in my hand. That was strange. I could feel how it was about to go off in my hand." (Ibidem.).

45 Ibidem.

46 Ibidem, p. 34.

47 Jacob talks to Jesus as if he is making a confession: "I take responsibility for that assassination... That... that was 
Nazi lieutenant ${ }^{48}$. At the end of the play, Jesus becomes the statue of Christ again. When the massacre is over in the church, the lieutenant starts to pray in front of the statue, and when he looks at the face of it, he "recognizes in Jesus' face the faces of the two men he just killed"49. Finally, the play ends with the nervous breakdown of the Nazi lieutenant because of a strong feeling of guilt.

Once again, it is possible to see how Lahola's play differs from other mentioned novels and movies because of its style, psychological approach and religious tone. However, all the works have the same aim, which is to narrate the Operation Anthropoid and its actors as efficiently as possible. Both the event and its protagonists inspired many writers to reimagine and retell the story using different approaches, which enables the audience to compare and contrast the way the event is narrated, as well as to remember such a tragic but honorable incident.

\section{Conclusion}

Beyond any doubt, historical fiction is one of the most efficient literary genres to discuss and elaborate on a past event. However, one cannot ignore the importance of the historical event in question. This paper tried to analyze the Operation Anthropoid and its representation in different literary and artistic works as well as to understand the reasons that make it quite distinguishable from other historical events. As it was mentioned before, apart from a historical context, heroes or villains of a story can make a historical incident even more interesting. The heroes of the Operation Anthropoid, Gabčík and Kubiš, were extraordinary individuals not only because of the assassination they carried out but also because of their personality traits. Similarly, the brutality of their enemy was one of a kind and has become the subject of many detailed analyses. It would be safe to claim that Gabčík, Kubiš and Heydrich have become perfect literary characters for the works that we have mentioned, and Linskey, Binet and Lahola enriched their stories and maybe even saved them from oblivion. In that sense, both the historical novelists and the heroes of the Operation Anthropoid help each other to amplify the story. Once again, we see how literature and real life are interconnected. Moreover, the Operation and the themes that are related to it, such as war, defense, political games, assassination, spying and resistance, are still very present in today's world and we see how history repeats itself with different heroes and villains. The reason why the Operation Anthropoid never loses its popularity and is constantly re-written by various novelists may be because of its timeless nature. The more we look at the past the better we understand the present. Indeed, as De Groot states: "The historical novel has a quality of revelation in that it can

my job. I mean... somehow I was best prepared for it...If it weren't for that miserable jump, I would have thrown the grenade... And perhaps many others..." (Ibidem, p. 65).

48 Jesus says to lieutenant: "You are already thinking about how to kill me. You are not thinking whether you should kill me. If you have the right to kill me. If it helps you if you kill me. As if I were the last person standing in your way, as if nobody came after me and you remained here, alone and victorious." (Ibidem, p. 77).

Ibidem, p. 80. 
change the past; it also encourages a particular set of responses and approaches." ${ }^{50}$ In that sense, the Operation Anthropoid not only changed the course of history, but it still continues changing the insight of today's audience.

\section{Bibliography}

BINET, Laurent: HHhH. Trans. by Sam Taylor. New York: Picador, 2012.

BURIAN, Michal - KNÍŽEK, Aleš - RAJLICH, Jiří - STEHLÍK, Eduard: Assassination. Trans. by Janua Agency. Prague: Ministry of Defence of the Czech Republic, 2002.

DE GROOT, Jerome: The Historical Novel. London and New York: Routledge, 2009.

ELLIS, Sean - FREWIN, Anthony: Anthropoid. Icon Home Entertainment, DVD, 2016.

FREUD, Sigmund: The Uncanny. Trans. by David McLintock. London: Penguin Books, 2003.

JARVIS, Brian: Monsters Inc.: Serial Killers and Consumer Culture. Crime Media Culture 3, 3: 2007, p. $326-344$.

JIMENEZ, Cédric - BINET, Laurent [et al.]: The Man with the Iron Heart. Lionsgate Home Entertainment, DVD, 2017.

LAHOLA, Leopold: Assassination. Eds. Vladimír Štefko - Slugeňová Cockrell, Katarína. Golden Collection of the Slovak Drama of the 20 $0^{\text {th }}$ Century (1900-1948). Bratislava: Divadelný ústav, 2016.

LEVIN, Jack - FOX, James Alan: Making Celebrities of Serial Killers Elevates Threat, 2002. https:// web.northeastern.edu/jfox/Columns/usatoday\%20monikers\%20oct\%2023.htm. Accessed May 2020.

LINSKEY, Howard. Hunting the Hangman. Harpenden: No Exit Press, 2017.

LINSKEY, Howard: Hunting the Hangman, QEFA with author Howard Linskey. Interview by Abby Slater-Fairbrother. Anne Bonny Book Reviews, May 18, 2017. https://annebonnybookreviews. $\mathrm{com} / \mathrm{tag} /$ operation-anthropoid.

MACDONALD, Callum: The Assassination of Reinhard Heydrich. Edinburgh: Birlinn Limited, 2007.

MARTIN, Keith: Vault of the Vampire (Fighting Fantasy \# 38). London: Puffin Books, 1989.

MARTIN, Keith: Revenge of the Vampire (Fighting Fantasy \# 58). London: Puffin Books, 1995.

MCLENNON, Leigh M.: 'The Red Thirst is on this Nation': Vampiric Hauntings and the American Civil War. In War Gothic in Literature and Culture, ed. by Agnieszka Soltysik Monnet - Steffen Hantke. New York: Routledge, 2016, p. 3-21.

PIERSON, Frank - LORING, Mandel: Conspiracy. Video Film Express, DVD, 2001.

TEICH, Mikuláš - KOVÁČ, Dušan - BROWN, Martin D. (eds.): Slovakia in History. New York: Cambridge University Press, 2011.

VIEWEG, W. - VICTOR, R. - DEMETRIOS, A. Julius [et al.]: "Posttraumatic Stress Disorder: Clinical Features, Pathophysiology, and Treatment" The American Journal of Medicine 119, 5, 2006, p. 383-390.

WILLOUGHBY, Ian: Last Days: The Heroes of Operation Anthropoid at Prague's Cyril and Methodius Church. Radio Prague International, 2017. https://www.radio.cz/en/section/czech-history/last-

50 DE GROOT, Jerome: The Historical Novel. London and New York: Routledge, 2009, p. 10. 
days-the-heroes-of-operation-anthropoid-at-pragues-cyril-and-methodius-church. Accessed May 16, 2020.

8 Villain Archetypes: How to Write Different Types of Villains. MasterClass, 2020. https://www.masterclass.com/articles/how-to-write-different-types-of-villains\#8-villain-archetypes. Accessed May 17, 2020.

Büke Sağlam, PhD fellow and researcher

Santiago de Compostela University, Faculty of Philology

Department of Spanish, Literary Theory and Linguistics

Room B15, Santiago de Compostela, ES

b.saglam@usc.es 